\title{
Application of PECS (Picture Exchange Communication System) to Improve The Expressive Language Skills of Autism Children
}

\author{
Mirnawati, Amka \\ Special Education Study Program \\ Faculty of Teacher Training and Education \\ Universitas Lambung Mangkurat \\ Banjarmasin, Indonesia \\ mirnawati.plb@ulm.ac.id
}

\begin{abstract}
This A person can interact with communication; communication can be established well if there is a two-way interaction or someone has the ability not only in expressive language but also in expressive language. Autistic children have limitations which are shown by the inability to express themselves effectively, so the child feels pressured to be able to express. Limitations of language skills can also cause emotions for children with autism because autistic children cannot express their wishes through communication messages. This study aims to improve the expressive language skills of autistic children in Banjarmasin SDLB YPLB through the use of the PECS (Picture Exchange Communication System) method. The method used in this study is a quasi-experimental design with a time series design (01 $020304 \times 05060708$ ). Subjects in this study were autistic students of grade IV SDLB YPLB in Banjarmasin. Data collection techniques use tests and documentation. Data collection instruments use verbal instructions and documentation tools. Data analysis techniques in this study used descriptive statistical data analysis. From the results of the expressive language ability of students at pre-test results obtained $01=27.502=32.503=$ 32.5 and $\mathrm{O} 4=35$. After being given treatment using the PECS method to improve the ability of expressive language can be seen from the activities of students during the learning process using the PECS method looks very enthusiastic and active. While the expressive language ability of students increased during the posttest with the results of $05=82.506=87.507=95$ and $08=100$. The ability of students to be seen from students can answer questions starting from exchanging objects that have been provided, mentioning, showing, up to composing several pictures to form collapsed sentences. Thus it can be concluded that the use of PECS media can improve the expressive language ability of grade 4 autistic children in Banjarmasin SDLB YPLB.
\end{abstract}

Keywords-PECS method; expressive language; children with autism

\section{INTRODUCTION}

Humans as social beings interact with their environment, especially interacting with fellow humans. Human interaction requires media interaction, namely communication. Communication is sending messages or information from someone to someone else. Through communication, interaction becomes more meaningful. With communication, humans can convey all their desires, convey information, express opinions, both verbally (through verbal) and non-verbal.

Not everyone can express or express what he wants and feels, one of them is a child with special needs, namely autism. Autism is a developmental disorder that hinders various aspects of a child's life. Autism is a severe developmental disorder which, among other things, affects the way a person communicates and reacts (interacts) with others because people with autism are unable to communicate verbally or nonverbally" [1 ]. According to reference [2], autism is a very complex/severe neurobiological development disorder in a long life, which includes disturbances in aspects of social interaction, communication and language, and behavior as well as emotional disturbances and sensory perceptions even on the motor aspects [2]

In general, children with autism have characteristics such as communication and language disorders, lack of social interaction and deviant interests and behaviors. One of these problems is communication and language; communication skills are one of the main obstacles that are characteristic of disorders in children with autism - factors that cause children to experience communication difficulties because children do not get a stimulus or stimulation from the surrounding environment. Therefore the development of communication in children with autism is very different, especially in children who experience severe obstacles in mastering the language and speaking.

Autistic children have limitations which are shown by the inability to express themselves effectively, so the child feels pressured to be able to express. Limitations of language skills can also cause emotions for children with autism because autistic children cannot communicate their wishes through communication messages. Limitations in capturing messages conveyed by other people and difficulties in responding to or answering conversations and limitations in expressing their desires make children with autism depressed. From communication and language problems can be an obstacle to autistic children to be able to develop other aspects of the lives 
of children with autism, such as developing social, emotional and other interactions.

Based on the results of observations carried out on autistic children in grade IV in Banjarmasin SDLB YPLB towards a student with the initials RJT, the child's eye contact was still lacking but the child could answer if his name were called, he could shake hands and mention his name when someone asked. Children can survive sitting for a long time, and are more cool with their toys, like to want objects played by their peers. There is one chance the child suddenly gives money to the researcher without knowing what is meant by the child, the researcher only holds the money, and the child starts pulling the hand of the researcher and takes the food the child wants and goes immediately after taking the food without paying it first. This condition shows that this autistic child has problems in expressive language skills.

The condition of such an autistic child certainly cannot be left alone, because after all he is part of the community and he is also a social creature that cannot be separated from a society that needs communication in his daily life. Thus one effort that can be done to improve the ability of children expressive language is to use the PECS method.

PECS (Picture Exchange Communication System) is an image-driven approach developed for children who experience shortages in social communication [3]. PECS therapy learning method is a therapeutic tool that can be made by parents themselves, and also the use of methods that are easy enough is expected to be able to help improve the language skills of autistic children. The PECS method is part of the AAC (Alternative Augmentative Communication) method. The PECS method has advantages compared to the Lovaas method which uses visual methods in the entire process of application. Autistic children have limitations in auditive terms because they cannot connect messages to the brain. This causes autistic children to be more likely to absorb what they see than what they hear. With the PECS method, activities during learning use more visual. The application of the PECS method in this study will develop expressive language skills in children by using communication aids in the form of picture cards and communication books. This is by the learning abilities of autistic children who are visual learning.

Based on the above problems, the purpose of this study is to improve the expressive language skills of autistic children in Banjarmasin SDLB YPLB through the use of the PECS (Picture Exchange Communication System) method.

\section{RESEARCH METHOD}

The approach used in this study uses a quantitative approach. According to reference [4], a quantitative approach can be interpreted as research based on the philosophy of positivism; research used to measure or sample, data collection techniques using research instruments and using data analysis [4]. The method used in this study is a quasi-experiment design research method. The research design-time series design according to reference [5] can be described as follows:

\section{$01020304 \times 05060708$}

Description:

- $\mathrm{O} 1 \mathrm{O} 2 \mathrm{O} 3 \mathrm{O} 4=$ Pretest to measure the first ability of the expressive language of autistic children before using the PECS method.

- $\mathrm{X}=$ Treatment or treatment that is implementation.

- $\mathrm{O} 5 \mathrm{O} 6 \mathrm{O} 7 \mathrm{O} 8=$ Posttest to re-measure the final ability of the expressive language of autistic children after being given the PECS method.

This research was conducted at SDLB YPLB in Banjarmasin City. The school is located on Jalan Yos Sudarso Gg 66 RT 32 Air Mantan Complex, West Banjarmasin District, Banjarmasin City, South Kalimantan Province. Private School Status. Subjects in this study were fourth-grade SDLB YPLB autistic students in Banjarmasin who experienced problems in expressive language skills. Data collection techniques using tests and observations, according to reference [6], tests are tools or procedures used to know or measure something in the atmosphere, by means and rules that have been determined, the criteria used in this study use action tests, the test is given to measure expressive language ability by means of the researcher gives so [6]. The form of the test used is an objective form consisting of right and wrong. The test in this study is divided into two, namely pretest and posttest. The test is used to measure the level of first ability of expressive language students before treatment. Whereas posttest was used to determine the increase in the results of interventions in expressive language skills of students. The documentation in this study is in the form of pictures/photographs to get an overview at the time of the research. The tools used are in the form of cameras and children's products. Data analysis techniques using descriptive statistics with the formula [7]. The description of the average score of students' ability level is based on the criteria in the following (Table 1):

TABLE I. Average Value of Student Ability

\begin{tabular}{|l|l|}
\hline \multicolumn{1}{|c|}{ Average Value } & \multicolumn{1}{c|}{ Description } \\
\hline $86-100$ & Very Good \\
\hline $76-85$ & Good \\
\hline $51-75$ & Good Enough \\
\hline $26-50$ & Not Good \\
\hline $0-25$ & Bad \\
\hline
\end{tabular}

\section{Result AND DiscusSiON}

\section{A. Pre Test (O1 O2 O3 O4)}

The pretest is carried out to determine the first ability of expressive child language. The results obtained by children at this pretest stage are:

TABle II. PRetest VAlue

\begin{tabular}{|l|l|}
\hline \multicolumn{1}{|c|}{ Pretest (O) } & \multicolumn{1}{c|}{ Pretest Value } \\
\hline O1 & 27,5 \\
\hline O2 & 32,5 \\
\hline O3 & 32,5 \\
\hline O4 & 35 \\
\hline
\end{tabular}




\section{B. Treatment $(X)$}

Implementation of the intervention is carried out through four phases, namely:

- Phase I: Initiation in communication, in this phase is focused so that children can exchange objects with images according to the initiative of the child.

- Phase II: Expansion of the Use of Images, Children respond by taking objects/food and the teacher directs the child to take and exchange it for the card the child wants.

- Phase III: Choosing a message in the PECS, Children are given a stimulus in the form of clothes and toys in turn. Then the child is faced with a card of two or more different images where one of them is the wrong picture, and the child selects the image that matches the object indicated by the teacher and gives the picture to the teacher.

- Phase IV: Expanding requests with attributes, in this phase the child is focused on being able to compile images into collapsed sentences. Children pay attention to the communication book that contains various kinds of images shown by the teacher. Then the teacher directs the child to compose sentences using models in the communication book

\section{Post Test (05 0607 O8)}

Posttest is a condition of repetition of the pretest phase as an evaluation of the extent to which the effect of treatment or intervention is given. The results of the data obtained are as follows:

TABLE III. Posttest VAlue

\begin{tabular}{|l|l|}
\hline \multicolumn{1}{|c|}{ Posttest (O) } & \multicolumn{1}{c|}{ Posttest Value } \\
\hline O5 & 82,5 \\
\hline O6 & 87,5 \\
\hline O7 & 95 \\
\hline O8 & 100 \\
\hline
\end{tabular}

The results of the study were based on the results of the pretest obtained by autistic students at SDLB YPLB Banjarmasin, before being given treatment the level of expressive language ability of students was still below the KKM standard. The results obtained by students during the pretest were $\mathrm{O} 1=27.5 \mathrm{O} 2=32.5 \mathrm{O} 3=32.5$ and $\mathrm{O} 4=35$. After being given treatment using the PECS method to improve the ability of expressive language can be seen from the activities of students during the learning process using the PECS method seen very enthusiastic and active. While the results obtained by students during posttest were $\mathrm{O} 5=82.5 \mathrm{O} 6$ $=87.5 \mathrm{O} 7=95$ and $\mathrm{O} 8=100$. Thus there was an increase in expressive language skills.

The enhancement of expressive language skills by using the PECS method is influenced by the use of drawing cards and concrete objects that are often encountered in children's daily lives in their application so that children are more accessible to answer the questions given. PECS (Picture
Exchange Communication System) is an image-driven approach developed for children who experience deficiencies in social communication [3].

Expressive language learning with the PECS method uses a variety of media including picture cards and communication books. This can increase children's learning interest in learning. According to reference [3] instructional media are learning media that are created and used and adapted to the conditions and needs of students/students with special needs. In addition, the benefits of using learning media is that it can help to overcome various kinds of obstacles including reducing the nature of verbalism, overcoming the limitations of space, time and type of student learning due to weakness in one of the senses, overcoming the teacher's difficulties in giving Learning services to students lighten the teacher's burden, and facilitate student or student learning [3].

The increase in expressive language skills obtained by autistic students shows that the use of the PECS method is very beneficial. The advantages of the PECS method itself in addition to developing communication for autistic children can also be used for other children who experience communication problems, especially spontaneous communication and social communication, and also excellent for children to improve social interaction. Because, image symbols are easy to understand, children can communicate with anyone, not only those who have been trained in using this method. Also, the materials used are also easily obtained and sought after because we can make it ourselves. This is also in line with research conducted by Ni Nyoman Sri Septiari (2015) that structured learning methods with PECS media can improve the tendency of positive communication in autistic children in Denpasar C1 State School of Special Education [8].

\section{CONCLUSION}

Based on the results of the study and discussion it can be concluded that the PECS method can improve expressive language skills in autistic children in Banjarmasin SDLB YPLB. This is shown from the results of the expressive language ability of students when pre-test results obtained $\mathrm{O} 1$ $=27.5 \mathrm{O} 2=32.5 \mathrm{O} 3=32.5$ and $\mathrm{O} 4=35$. After being given treatment using the PECS method to improve the ability of expressive language can be seen from the activities of students during the learning process using the PECS method looks very enthusiastic and active. While the expressive language ability of students increased during the post-test with the results of $\mathrm{O} 5=82.5 \mathrm{O} 6=87.5 \mathrm{O} 7=95$ and $\mathrm{O} 8=100$. The ability of students to be seen from students can answer questions starting from exchanging objects that have been provided, mentioning, showing, up to composing several pictures to form collapsed sentences.

\section{REFERENCES}

[1] D. Koswara, Pendidikan Anak Berkebutuhan Khusus Autis. Jakarta: PT Luxima Metro Media, 2013.

[2] J. Yuwono, Memahami Anak Autistik (Kajian Teoritik dan Empirik). Bandung: Alfabeta, 2012.

[3] Y. C. Meimulyani, Media Pembelajaran Adaftif bagi Anak Berkebutuhan Khusus. Jakarta: PT Luxima Metro Media, 2013. 
[4] Sugiyono, Metodologi Penelitian Pendidikan, Pendekatan Kuantitatif, Kualitatif, dan R \& D. Bandung: Alfabeta, 2013.

[5] Wahyu, Metodologi Penelitian Kuantitatif. Banjarmasin: Universitas Lambung Mangkurat FKIP, 2012.

[6] S. Arikunto, Dasar-dasar Evaluasi Pendidikan. Jakarta: Bumi Aksara, 2013.

[7] Sugiyono, Metode Penelitian Kuantitatif, Kualitatif, dan R\&D, Cetakan Ke-10. Bandung: Alfabeta, 2010.

[8] N. N. S. Septiari, N. K. Suarni, I. N. Jampel,"Pengaruh metode pembelajaran terstruktur dengan media Pecs untuk meningkatkan komunikasi pada anak autis di SLB C1 Negeri Denpasar Tahun Ajaran 2014/2015," e-Journal Program Pascasarjana Universitas Pendidikan Ganesha Program Studi Penelitian dan Evaluasi Pendidikan, vol. 5, no. $1,2015$. 